\title{
DÜBLIN
}

Technological University Dublin

ARROW@TU Dublin

2010-01-01

\section{Growth and Kinetics of Lactobacillus Plantarum in the Fermentation of Edible Irish Brown Seaweeds}

\author{
Shilpi Gupta \\ Technological University Dublin, shilpi.19may@gmail.com \\ Nissreen Abu-Ghannam \\ Technological University Dublin, nissreen.abughannam@tudublin.ie \\ Amalia G.M. Scannell \\ University College Dublin, amalia.scannell@ucd.ie
}

Follow this and additional works at: https://arrow.tudublin.ie/schfsehart

Part of the Food Biotechnology Commons, Food Microbiology Commons, and the Food Processing Commons

\section{Recommended Citation}

Gupta,S.,et al. (2010) Growth and kinetics of Lactobacillus plantarum in the fermentation of edible Irish brown seaweeds. Food Bioprod Process, doi:10.1016/j.fbp.2010.10.001

This Article is brought to you for free and open access by the School of Food Science and Environmental Health at ARROW@TU Dublin. It has been accepted for inclusion in Articles by an authorized administrator of ARROW@TU

Dublin. For more information, please contact

arrow.admin@tudublin.ie, aisling.coyne@tudublin.ie, gerard.connolly@tudublin.ie.

Funder: Strand III, Irish Government

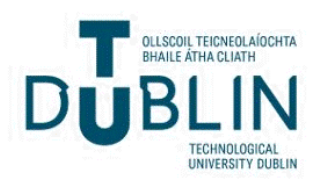




\title{
Growth and kinetics of Lactobacillus plantarum in the fermentation of edible Irish brown seaweeds
}

\author{
Shilpi Gupta ${ }^{a}$, Nissreen Abu-Ghannam ${ }^{a, *}$, Amalia G.M. Scannell ${ }^{b}$ \\ a School of Food Science and Environmental Health, Dublin Institute of Technology, Cathal Brugha St., Dublin 1, Ireland \\ $\mathrm{b}$ University College Dublin, School of Agriculture, Food Science and Veterinary Medicine, College of Life Science, Belfield, Dublin 4, Ireland
}

\begin{abstract}
A B S T R A C T
The aim of the present study was to see the applicability of using brown edible seaweeds as a sole source of nutrition for the growth of lactic acid bacteria. Growth kinetics of lactic acid bacteria (LAB; Lactobacillus plantarum) was studied using three species of edible Irish brown seaweeds Himanthalia elongata, Laminaria digitata and Laminaria saccharina. As part of the screening process, growth of the LAB was carried out on raw and heat treated forms of seaweeds. The seaweed species in their raw state could not support the growth of L. plantarum. Heat treatment resulted in almost 4 times increase in the total sugar content in L. digitata and L. saccharina broth which allowed the growth of L. plantarum for $24 \mathrm{~h}$ after which the cell number started decreasing. The Laminaria spp. contains a high content of laminaran polysaccharide which can be fermented by LAB. In case of H. elongata, neither raw nor heat treated forms could be fermented; even though the total sugar content increased 4.6 times upon the application of heat. Kinetics of cell growth, lactic acid and acetic acid production was evaluated at different agitation rates in heat treated seaweeds. A maximum log CFU/ml of 10 was achieved at the end of $16-24 \mathrm{~h}$ of fermentation for L. saccharina and L. digitata, respectively. The cell growth increased and lactic acid accumulation decreased as the agitation speed was increased from 0 to $100 \mathrm{rpm}$. Maximum lactic acid accumulation of $2.5 \mathrm{~g} / \mathrm{l}$ was achieved under static $(0 \mathrm{rpm})$ conditions. The production of acetic acid was very minimal during the entire course of fermentation. Experimental data was mathematically modelled to optimize the cell growth and lactic acid production with respect to the different rotation conditions. The results of this study present an indication of the potential of fermentation of seaweeds using LAB with a possibility towards the development of a range of functional foods.
\end{abstract}

๑ 2010 The Institution of Chemical Engineers. Published by Elsevier B.V. All rights reserved.

Keywords: Fermentation; Lactic acid; Edible brown seaweed; Heat processing; Mathematical modelling

\section{Introduction}

In recent years, consumer demand for non-dairy-based probiotic products has increased (Luckow and Delahunty, 2004) due to the problems of lactose intolerance and cholesterol content associated with the consumption of fermented dairy products. In this respect, vegetables offer an alternative for the production of probiotic foods due to their large distribution and nutritive value. Lactic acid fermentation can help to improve the safety, shelf life, nutritional and sensory properties of vegetables (Karovićová and Kohajdová, 2003).

Production of plant based fermented products, although common, has been limited to the use of terrestrial plants and those prepared from aquatic materials are quite limited.
Several reports are available on the use of terrestrial vegetables for lactic acid fermentation such as artichokes (Ge et al., 2009), carrot (Kun et al., 2008; Bergqvist et al., 2005), cabbage (Kohajdová et al., 2006; Yoon et al., 2006), beet root (Yoon et al., 2005), onions (Roberts and Kidd, 2005) and cucumber (Daeschel et al., 1988). However, the use of algal materials for the production of edible fermented products has been limited. Seaweed, Undaria pinnatifida, has been utilized as a means for the development of an alternative diet for feeding fish in aquaculture using cellulose for saccharification of seaweeds and performing fermentation by inoculating a microbial mixture (Uchida and Murata, 2002). Ennouali et al. (2006) fermented the garbage of red seaweed, obtained after extraction of agar-agar, with $\mathrm{LAB}$ and yeast to be used as a fertilizer. Prachyakij et al.

\footnotetext{
* Corresponding author. Tel.: +353 14027570.

E-mail addresses: nissreen.abughannam@dit.ie, shilpi.19may@gmail.com (N. Abu-Ghannam).

Received 18 March 2010; Received in revised form 27 August 2010; Accepted 8 October 2010 0960-3085/\$ - see front matter @ 2010 The Institution of Chemical Engineers. Published by Elsevier B.V. All rights reserved. doi:10.1016/j.fbp.2010.10.001
} 
(2008) produced a fermented beverage from seaweed Gracilaria fisheri. Other reports are available wherein researchers have isolated and fermented polysaccharides present in seaweeds (Michel et al., 1996).

Seaweeds are a good source of bioactive compounds as they are able to produce a great variety of secondary metabolites characterized by a broad spectrum of biological activities. The precise nutritional properties of seaweeds are not as well known as are those of land plants, but several research works have shown that they are low in lipids but rich in proteins, non-starch polysaccharides, minerals and vitamins (Fleurence, 1999; Mabeau and Fleurence, 1993). Polysaccharides from seaweeds have been reported to possess biological activities of potential medicinal values in addition to their current status as a source of dietary fibres and prebiotics (Smit, 2004). The human consumption of algal fibre promotes the growth and protection of the beneficial intestinal flora, greatly increases stool volume and reduces the risk of colon cancer Brown seaweeds are reported to be rich in insoluble (cellulose) and soluble (laminarans, fucans and alginates) form of dietary fibres (Michel et al., 1996; Suzuki et al., 1996). Alginate and laminaran have been reported to be fermented by some strains of Bacteroides and Clostridium (Kuda et al., 1998). Previous studies report a positive effect of feeding 10\% laminaran containing diets on the faecal microflora of rats (Kuda et al., 1992a). Kuda et al. (1992b) also reported that the growth of intestinal bacteria was promoted when they were grown in a medium rich in degraded products from laminaran. All these studies support the fact that polysaccharides present in seaweeds have the potential to be fermented and thus makes seaweeds an attractive option for the development of fermented foods.

Strains of several Lactobacillus species have proven to exert a range of health promoting activities such as immunomodulation, enhancement of resistance against pathogens, reduction of blood cholesterol levels and are used as probiotics (de Vries et al., 2006). Production of lactic acid during fermentation by microorganisms can be affected by medium composition (carbohydrate source, sugar concentration and growth factors), the presence of oxygen, $\mathrm{pH}$ and product concentration (Burgos-Rubio et al., 2000). Fu and Mathews (1999) studied lactic acid production from lactose by Lactobacillus plantarum and found the cell yield to be higher under aerobic conditions whereas lactic acid production was higher under anaerobic conditions. Murphy and Condon (1984) reported the main end product of aerobic and anaerobic conditions to be acetic and lactic acid, respectively, thus demonstrating the significance of aeration in the optimization of fermentation processes.

There is now an increasing interest in modelling the kinetics of beneficial microorganisms in food systems. Bello and Sánchez Fuertes (1995) developed a mathematical equation to describe the behavior of the Lactobacillus species during the ripening of Spanish "chorizo". Kedia et al. (2008) used an unstructured mathematical model to describe the kinetics of lactic acid bacteria in an oat based media. Cell growth, metabolic product formation and substrate uptake were monitored over the entire fermentation period and the results were fitted to an unstructured model. Cagno et al. (2008) carried out the selection of a starter culture on the basis of rates of growth and acidification in vegetable juice media. Growth and acidification data were modelled according to the Gompertz equation. Kinetics of growth and acid production by $L$. plantarum was also studied for the fermentation of tomato juice (Cagno et al., 2009). Echevarria et al. (2010) applied the
Quasi-chemical primary model to study the evolution of yeast and lactic acid bacteria populations during the storage of Manzanilla-Aloreña table olives subjected to different mixtures of ascorbic acid, sodium metabisulphite and $\mathrm{NaCl}$. These mathematical tools help to deliver a better understanding of the fermentation course and may lead to the development of improved strategies for the optimization of the fermentation process to ensure its economical viability.

This work is part of an ongoing project to evaluate the potential of seaweeds as a substrate for the development of a probiotic product. However, due to the complexity of seaweeds, a systematic approach is needed in order to identify the factors, which would allow the growth of LAB initially so that these studies can form a platform for the fermentation of seaweeds later with probiotic strains. The use of probiotic bacteria as starter cultures is not very common as this might compromise the potential health benefits of the probiotic strain and affect the technological suitability of the strain. For this reason, the present work involved the use of lactic acid bacteria to study the applicability of seaweeds as a medium for growth. Due to their abundance in Ireland, good value and high nutritional content, three edible Irish brown seaweeds were selected for this study. Both Laminaria saccharina and Laminaria digitata are rich in the polysaccharide laminaran and Himanthalia elongata is rich in fucoidan. The aim of the present work was to assess the fermentative capability of seaweeds as a sole source of nutrition for the growth of L. plantarum ATCC 8014. For initial screening studies raw and heat treated form of seaweeds were used to check which type of seaweed would allow the growth of LAB. Thereafter, the effects of different aeration conditions (in a flask) on the course of cell growth and lactic acid production during fermentation were also analyzed. Additionally, time courses of the growth and lactic acid production under different rotation conditions were mathematically modelled.

\section{Materials and methods}

\subsection{Seaweed material}

Three species of brown seaweeds namely, L. digitata, L. saccharina and H. elongata (Phaeophyta) were purchased from Quality Sea Veg., Co Donegal, Ireland. Samples were collected in June 2009, washed thoroughly with freshwater to remove epiphytes and eliminate foreign materials such as sand or shells and stored at $-18^{\circ} \mathrm{C}$ until analysis.

\subsection{Culture}

L. plantarum ATCC 8014 was purchased from Medical Supply Company, Dublin, Ireland. The culture was maintained at $-70^{\circ} \mathrm{C}$ in $20 \%$ glycerol stocks and grown in Man Rossa de Sharpe (MRS; (Scharlau Chemie, Barcelona, Spain)) broth at $37^{\circ} \mathrm{C}$.

\subsection{Inoculum preparation}

For the preparation of inoculum, $25 \mathrm{ml}$ of sterile MRS broth was inoculated with $1 \mathrm{ml}$ of thawed stock culture and incubated at $37^{\circ} \mathrm{C}$ for $12-14 \mathrm{~h}$. This was then serially diluted 100 times to obtain working culture containing $6-7 \log \mathrm{CFU} / \mathrm{ml}$ cells as determined by plate counts. 


\subsection{Fermentation}

In order to check for the applicability of seaweeds as a growth medium for LAB, preliminary experiments involved screening of raw and heat treated seaweeds. Heat treatment was carried out in an autoclave (Tomy SS-325, Tomy Seiko Co Ltd., Tokyo, Japan) at $95^{\circ} \mathrm{C}$ for $15 \mathrm{~min}$. The conditions for heat treatment were chosen on the basis of our previous studies (Gupta et al., 2010). Seaweeds were washed, chopped into small pieces $(2 \mathrm{~cm} \times 0.5 \mathrm{~cm})$ and $5 \mathrm{~g}$ were taken in a $100 \mathrm{ml}$ Erlenmeyer flask and $24 \mathrm{ml}$ deionized water was added. The flasks containing seaweed and water (hereafter called seaweed broth) were autoclaved at the required conditions $\left(95^{\circ} \mathrm{C}\right.$ for $\left.15 \mathrm{~min}\right)$ and inoculated with $4 \%$ inoculum $(1 \mathrm{ml})$ upon cooling. In case of raw seaweeds, flasks containing $24 \mathrm{ml}$ water were sterilized separately. Pre-washed chopped seaweeds $(5 \mathrm{~g})$ were added to flasks under sterile conditions, followed by inoculation with $4 \%$ inoculum. The flasks were incubated at $37^{\circ} \mathrm{C}$ and $50 \mathrm{rpm}$ (Innova 42, Mason Technology, Ireland). Samples were taken at $0,24,48$, and $72 \mathrm{~h}$ for microbiological analysis and total sugar content.

\subsection{Effect of agitation}

Since heat treatment resulted in a better growth of LAB, the next step was to assess the effect of agitation. Flasks containing $10 \mathrm{~g}$ chopped seaweeds were mixed with $48 \mathrm{ml}$ de-ionized water in a $200 \mathrm{ml}$ Erlenmeyer flask and heated in an autoclave at $95^{\circ} \mathrm{C}$ for $15 \mathrm{~min}$. The flasks were cooled to room temperature and inoculated with $4 \%$ inoculum $(2 \mathrm{ml})$. Thereafter they were incubated at $37^{\circ} \mathrm{C}$ at an agitation speed of 0,50 and $100 \mathrm{rpm}$ to see the effect of rotation on the growth kinetics and lactic acid production by L. plantarum. For 0 rpm, the flasks were stored under static conditions in the incubator. Samples were withdrawn every 3-4h for $24 \mathrm{~h}$. Since anaerobic conditions are difficult to achieve in Erlenmeyer flasks, static flasks (0 rpm) were considered as equivalent to having microaerophillic conditions. The fermented broth was analyzed for viable counts, acid production and total sugar content. Growth data from plate counts were enumerated as $\log _{10}$ values.

\subsection{Analytical methods}

The $\mathrm{pH}$ of fermented seaweeds was measured with a $\mathrm{pH}$ meter. Viable cell counts in the seaweed broth $(\log \mathrm{CFU} / \mathrm{ml})$ were determined by the standard plate method with MRS medium. Dilution of $1 \mathrm{ml}$ broth was carried out in $9 \mathrm{ml}$ MRD to plate the suitable dilution. The plates were incubated at $37^{\circ} \mathrm{C}$ for $36-48 \mathrm{~h}$ for cell enumeration.

Each sample of the fermented broth was centrifuged at $10,000 \mathrm{rpm}$ for $15 \mathrm{~min}$ at $4{ }^{\circ} \mathrm{C}$. The supernatant was subject to analyses of organic acids and total sugar. Total sugars in the centrifuged seaweed broth were estimated by the phenolsulphuric acid method (Mecozzi, 2005; Dubois et al., 1956).

The cell-free supernatant of fermented broth was used for the determination of organic acids by HPLC. The analyses were carried out using the Waters HPLC System consisting of W600 controller, Waters 717 plus autosampler and Waters 2996 Photodiode array detector. The detection of organic acids was carried out at a wavelength of $210 \mathrm{~nm}$. Samples and mobile phases were filtered through a $0.22 \mu \mathrm{m}$ Millipore filter (Millipore, Bedford, MA) prior to HPLC injection and $20 \mu$ l of sample was injected. A thermostatically controlled compartment set at $30^{\circ} \mathrm{C}$ containing Develosil (Nomura Chemical Co., Japan)
C30-UG-5 (150 $\mathrm{mm} \times 4.6 \mathrm{~mm}$ ) column was used at a flow rate of $0.9 \mathrm{ml} / \mathrm{min}$ using $0.05 \mathrm{M} \mathrm{NH}_{4} \mathrm{H}_{2} \mathrm{PO}_{4}$ (Sigma-Aldrich, Germany) with $\mathrm{H}_{3} \mathrm{PO}_{4}$ (Sigma-Aldrich, Germany) (pH 2.4) as the mobile phase. The data acquisition and integration were performed using the Empower ${ }^{\mathrm{TM}} 4.0$ software package. Each sample was injected two times. Standards for the organic acids (lactic, acetic, malic and citric) were used to identify and quantify the components in the samples.

\subsection{Mathematical modelling}

The modified Gompertz equation (Zwietering et al., 1990) was fitted to the logarithm of the cell concentration in order to estimate the maximum specific growth rates, lag phase and maximum cell number achieved of $L$. plantarum under different agitation conditions. The model is described by the equation:

$\log \left(\frac{N}{N_{0}}\right)=A \times \exp \left\{-\exp \left[\frac{\mu \times e}{A}(\lambda-t)+1\right]\right\}$

where $\mu_{\max }$ is the maximum specific growth rate of cell population, $A$ is the log increase in population and $\lambda$ is a delayed time variable (lag phase), $N$ is the CFU/ml at any time $t, N_{0}$ is the initial CFU $/ \mathrm{ml}$. Estimates of these parameters have been based on the assumptions of the Gompertz equation that the rate of growth is proportional to cell mass and that the growth rate decays exponentially with time due to inactivation of the bacteria (Schofield et al., 1994). Thus the basic assumption of model has been well satisfied.

The fermentative production of lactic acid production upon different rotation speeds was described by Eq. (2) (Mercier et al., 1992). This equation is based on the assumptions of logistic model which is suitable for the adjustment of the typical sigmoid profiles and facilitates the calculation of parameters of biological significance.

$\frac{d P}{d t}=P_{r} \times P\left(1-\frac{P}{P_{m}}\right)$

where $t$ is time, $P$ is lactic acid concentration $(g / l), P_{m}$ is the maximum concentration of lactic acid $(g / l), P_{r}$ is the ratio between the initial volumetric rate of product formation $\left(r_{p}\right)$ and the initial product concentration $P_{0}\left(h^{-1}\right)$. Eq. (2) can be solved to give the following expression:

$P=\frac{P_{0} P_{m} e^{P_{r} t}}{P_{m}-P_{0}+P_{0} e^{P_{r} t}}$

The value of model parameters $\left(A, \mu, \lambda, P_{0}, P_{m}\right.$ and $\left.P_{r}\right)$ was fitted with a Marquardt algorithm, using the STATGRAPHICS Centurion XV (StatPoint Technologies, Inc., Warrenton, VA) statistical software.

\section{Statistical analysis}

All experiments were carried out in triplicate, and each sample was analyzed in duplicate. The results were expressed as mean \pm SD (standard deviation). All statistical analyses were carried out using STATGRAPHICS Centurion XV. Statistical differences between different fermented broths were determined using ANOVA followed by Least Significant Difference (LSD) testing. Differences were considered statistically significant when $P<0.05$ 


\section{Results and discussion}

\subsection{Fermentation of raw and heat treated seaweeds}

\subsubsection{H. elongata}

Since there are no specific regulations governing the collection of seaweeds from coastal regions, they may be collected from inshore marine waters as well as from agricultural run-off which could be a source of contamination. In order to prevent the growth of spoilage organisms during fermentation, it was important to find out the indigenous microflora present on seaweeds. In our previous studies, we had analyzed the effect of temperature on the microbiological quality of seaweeds (Gupta et al., 2010) and found the raw seaweeds and those heated at $95^{\circ} \mathrm{C}$ for $15 \mathrm{~min}$ to be of good microbiological quality as indicated by complete absence of any detectable bacteria or fungi. Heat treatment may serve to: (1) eliminate surface microflora, (2) produce a palatable product, and (3) enhance the availability of nutrients. Commercially in processing plants or domestically in household kitchens, fruits and vegetables routinely undergo heat treatment. One of the aims of this study was to find the applicability of seaweeds as a sole source of nutrients for the growth and metabolism of L. plantarum. In order to compare which form of seaweeds would allow the growth of L. plantarum, trials were carried out using either raw or seaweeds heated at $95^{\circ} \mathrm{C}$ for $15 \mathrm{~min}$. Flasks containing seaweeds and water were heat treated and inoculated with $4 \% \mathrm{~L}$. plantarum. In case of raw seaweeds, flasks containing water were sterilized separately and raw seaweeds were added under sterile conditions and then inoculated with $4 \%$ L. plantarum. During the initial trials to ferment seaweeds, cell concentration of L. plantarum was kept high $(7-8 \log$ CFU/ml) in order to check if the seaweed broth is able to sustain the growth of bacteria. The time course for the growth of L. plantarum with $\mathrm{H}$. elongata at the two different processing conditions is shown in Table 1. It was observed that neither raw nor heat processed form was able to support the growth of L. plantarum (Table 1) even though the total sugar content was found to be $2.4 \pm 0.1 \mathrm{~g} / \mathrm{l}$ for raw seaweed which increased almost 4.6 times upon heating. The reason for this could be the presence of fucoidans in $H$. elongata. Fucoidans are sulphated polysaccharides containing L-fucose as the main sugar constituent and sulphate esters. Studies carried out by Michel et al. (1996) have shown that high concentrations of fucose and sulphate as well as their particular arrangement in brown algal fibre are probably responsible for their resistance to bacterial degradation and seaweeds containing laminaran ferment more readily than those containing the sugars fucoidans (Michel et al., 1996). Human intestinal bacteria also ferment sodium alginate and laminaran but not fucoidan and cellulose (Fujii, 1992). The results obtained from the present study followed a similar pattern. Consequently, H. elongata was not used for any further studies based on the results of these initial experiments.

\subsubsection{L. digitata and L. saccharina}

In case of L. digitata and L. saccharina again it was seen that neither of the seaweed species could sustain the growth of $L$. plantarum in the raw state. Since seaweeds had not undergone any treatment which could promote the release of nutrients in the broth the total sugar content was expected to be quite low. It was found to be only $0.57 \pm 0.006$ and $0.6 \pm 0.014 \mathrm{~g} / \mathrm{l}$ for L. digitata and L. saccharina, respectively, which might not be sufficient for the growth of LAB. Buruleanu et al. (2010) have also suggested that the initial amount of sugars is important to be enough for lactic acid bacteria growth and multiplication. Heat treatment $\left(95^{\circ} \mathrm{C}\right.$ for $15 \mathrm{~min}$ ) of L. saccharina and L. digitata resulted in 3.5- and 3.9-fold increase in the total sugar content (Table 1), respectively. The seaweed broth from both the species was able to support the growth of L. plantarum without nutrient supplementation for $24 \mathrm{~h}$ (Table 1). There was a significant difference in the growth of L. plantarum between 0 and $24 \mathrm{~h}$. Extending the fermentation period beyond $24 \mathrm{~h}$ resulted in a significant decrease in the viable cell counts of L. plantarum $(P<0.05)$ for $L$. saccharina and L. digitata heat treated at $95^{\circ} \mathrm{C}$ for $15 \mathrm{~min}$. Heating resulted in leaching of sugars from seaweeds into the water and thus helped LAB to grow. The results obtained in the present study were contradictory to those reported by Gardner et al. (2001) who did not find any significant difference in the sugar content of pasteurized, sterilized and control vegetable juice. At the same time, our previous study showed that heating resulted in reduction of antimicrobial activity of the seaweeds (Gupta et al., 2010). Similar facts have been reported in case of cabbage as well. Kyung and Fleming (1994) reported that fresh juice of Cecile cultivar cabbage was inhibitory to the growth of LAB due to the presence of antibacterial substances in juice, and the inhibition was eliminated when the cabbage was heated (steamed $10 \mathrm{~min}$ ) before juice extraction.

Preliminary studies showed that heat treated L. digitata and L. saccharina maintained the growth of L. plantarum for $24 \mathrm{~h}$. $\mathrm{L}$. plantarum is a facultative bacterium and can utilize oxygen as electron acceptor for cell growth and for product metabolism. However, many LAB also have the ability to degrade lactic acid, especially if $\mathrm{O}_{2}$ is available as an electron acceptor. Lactate initially formed from glucose is aerobically converted to acetate after glucose exhaustion (Murphy et al., 1985; Kandler, 1983). Some studies in synthetic lactose medium showed that L. plantarum can give high cell numbers under aerobic conditions and higher lactic acid production under anaerobic conditions (Fu and Mathews, 1999). Since the data on the use of seaweeds for fermentation and lactic acid production is very scarce, it was therefore desirable to comparatively evaluate growth and lactic acid fermentation under different agitation conditions which will eventually lead to different aeration conditions.

\subsection{Effect of agitation}

The flasks containing seaweed broth (heated at $95^{\circ} \mathrm{C}$ for $15 \mathrm{~min}$ ) and L. plantarum were incubated at 0 (microaerophillic), 50 (aerobic) and $100 \mathrm{rpm}$ (aerobic). A different agitation rate was assumed to be producing different aeration conditions within the flasks. The time course for the growth of L. saccharina can be seen in Table 2. The fact that L. plantarum could readily utilize the sugars, leached out in the broth, for growth was evident from the minimal lag phase and increase in cell numbers within $3 \mathrm{~h}$ of growth. Kun et al. (2008) also reported complete absence of lag phase during the fermentation of heat treated carrot juice with Bifidobacterium strains. Cell concentration in the present study increased from $6 \log \mathrm{CFU} / \mathrm{ml}$ to $9.7 \log \mathrm{CFU} / \mathrm{ml}$ after $16 \mathrm{~h}$ of incubation with a kinetic profile that was fairly described by the Gompertz equation $\left(R^{2}>0.962\right)$ (Fig. 1). Such a cell growth led to the consumption of $0.7-1.1 \mathrm{~g} / \mathrm{l}$ total sugar. If the culture is provided with favourable conditions during fermentation, then it results in accelerated growth phase; hence it can be said the maximum specific growth rate is 
Table 1 - Growth of L. plantarum in raw and heat treated Irish edible brown seaweeds.

\begin{tabular}{|c|c|c|c|c|c|}
\hline \multirow[t]{2}{*}{ Species } & \multirow[t]{2}{*}{ Treatment } & \multicolumn{4}{|l|}{ Time (h) } \\
\hline & & 0 & 24 & 48 & 72 \\
\hline \multirow[t]{6}{*}{ L. digitata } & Raw & & & & \\
\hline & CFU & $7.8 \pm 0.1^{\mathrm{a}}$ & $4.5 \pm 0.07^{b}$ & $2.3 \pm 0.04^{c}$ & $0^{\mathrm{d}}$ \\
\hline & TS $(g / 1)$ & $0.57 \pm 0.006^{a}$ & $0.56 \pm 0.01^{\mathrm{a}}$ & $0.56 \pm 0.09^{\mathrm{a}}$ & $0.57 \pm 0.06^{\mathrm{a}}$ \\
\hline & $95^{\circ} \mathrm{C} / 15 \mathrm{~min}$ & & & & \\
\hline & CFU & $8.1 \pm 0.1^{\mathrm{a}}$ & $8.5 \pm 0.1^{b}$ & $8.6 \pm 0.1^{b}$ & $6.8 \pm 0.2^{c}$ \\
\hline & TS (g/l) & $2.2 \pm 0.03^{a}$ & $2.1 \pm 0.06^{a}$ & $2.05 \pm 0.08^{b}$ & $1.9 \pm 0.1^{\mathrm{c}}$ \\
\hline \multirow[t]{6}{*}{ L. saccharina } & Raw & & & & \\
\hline & CFU & $7.8 \pm 0.01^{\mathrm{a}}$ & $7.7 \pm 0.06^{b}$ & $5.1 \pm 0.2^{c}$ & $2.3 \pm 0.09^{\mathrm{d}}$ \\
\hline & TS $(\mathrm{g} / \mathrm{l})$ & $0.6 \pm 0.014^{\mathrm{a}}$ & $0.57 \pm 0.1^{\mathrm{a}}$ & $0.59 \pm 0.07^{\mathrm{a}}$ & $0.58 \pm 0.09^{\mathrm{a}}$ \\
\hline & $95^{\circ} \mathrm{C} / 15 \mathrm{~min}$ & & & & \\
\hline & CFU & $7.9 \pm 0.02^{\mathrm{a}}$ & $8.4 \pm 0.08^{b}$ & $6.9 \pm 0.03^{c}$ & $5.5 \pm 0.1^{\mathrm{d}}$ \\
\hline & TS (g/l) & $2.12 \pm 0.02^{\mathrm{a}}$ & $2.1 \pm 0.1^{\mathrm{a}}$ & $2.07 \pm 0.04^{\mathrm{ab}}$ & $2 \pm 0.03^{b}$ \\
\hline \multirow{6}{*}{ H. elongata } & Raw & & & & \\
\hline & $\mathrm{CFU}$ & $8.4 \pm 0.1^{\mathrm{a}}$ & $5.7 \pm 0.2^{b}$ & $4.7 \pm 0.2^{c}$ & $3.7 \pm 0.1^{\mathrm{d}}$ \\
\hline & TS $(g / 1)$ & $2.4 \pm 0.1^{\mathrm{a}}$ & $2.43 \pm 0.09^{a}$ & $2.42 \pm 0.1^{\mathrm{a}}$ & $2.4 \pm 0.05^{\mathrm{a}}$ \\
\hline & $95^{\circ} \mathrm{C} / 15 \mathrm{~min}$ & & & & \\
\hline & CFU & $8.6 \pm 0.03^{a}$ & $5.8 \pm 0.1^{b}$ & $4.8 \pm 0.1^{c}$ & $4.3 \pm 0.4^{\mathrm{d}}$ \\
\hline & TS $(g / l)$ & $11.7 \pm 0.2^{\mathrm{a}}$ & $11.7 \pm 0.08^{a}$ & $12.5 \pm 0.07^{b}$ & $11.9 \pm 0.1^{\mathrm{a}}$ \\
\hline
\end{tabular}

Results are expressed as mean \pm SD. TS: total sugars (g/l). CFU: log CFU/ml. Superscript letters: mean \pm SD in a row are significantly different by least significance difference $(P<0.05)$. Significance test was done for raw and heat treated $\left(95^{\circ} \mathrm{C} / 15 \mathrm{~min}\right)$ seaweeds with respect to $\mathrm{CFU}$ and $\mathrm{TS}$ for the entire fermentation period $(0-72 \mathrm{~h})$.

the response that defines the fermentation process. The use of the Gompertz equation to describe the growth kinetics of $L$. plantarum was useful in quantifying the lag period $(\lambda)$, the maximum specific growth rate $\left(\mu_{\max }\right)$ and the log increase in population (A) reached in the culture, which are parameters with biological meaning. In past as well, Gompertz equation has been used to model the growth kinetics of LAB (Cagno et al., 2008, 2009). These parameters clearly helped in distinguishing the effect of rotation on L. plantarum growth kinetics. The parameter ' $A$ ' (log increase in population) was found to increase and the specific growth rate ' $\mu$ ' decreased with the increase in rotation speed (Table 3). Significant differences $(P<0.05)$ in the lag phase and specific growth rate were seen for the flasks incubated at $0 \mathrm{rpm}$ and those incubated under agitated (50 and $100 \mathrm{rpm}$ ) conditions (Table 3). The lag phase ' $\lambda$ ', although present, was very minimal. Extending the fermentation beyond $16 \mathrm{~h}$ resulted in a reduction in the viable cell counts of L. plantarum. Speed of agitation showed a significant effect on the bacterial growth. For example, the growth at $0 \mathrm{rpm}$ was significantly different from 50 and $100 \mathrm{rpm}$ all through the growth phase $(P<0.05)$. During the exponential phase (from $9 \mathrm{~h}$ to $16 \mathrm{~h}$ ), significant difference in

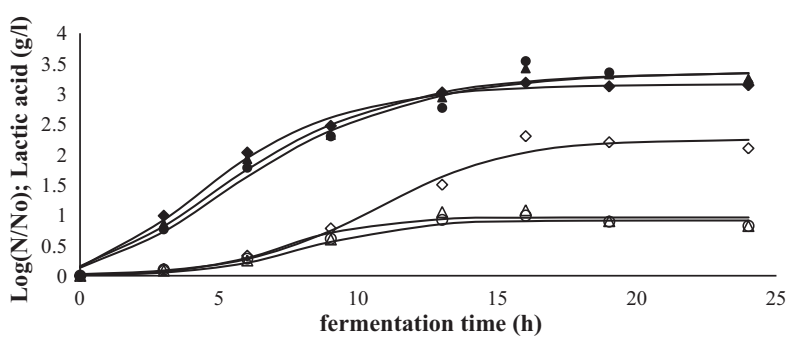

Fig. 1 - Cell growth and lactic acid production with $L$. saccharina under different rotation conditions. Legends for $\log \left(\mathrm{N} / \mathrm{N}_{0}\right) \diamond-0 \mathrm{rpm} ; \Delta-50 \mathrm{rpm} ; \bullet-100 \mathrm{rpm}$; Legend for lactic acid $\diamond-0 \mathrm{rpm} ; \Delta-50 \mathrm{rpm} ; \bigcirc-100 \mathrm{rpm}$. Smooth lines - model simulated; Points - experimental data. the $\log \mathrm{CFU} / \mathrm{ml}$ was seen for the flasks rotated at the three rpm $(P<0.05)$ whereby maximum log CFU/ml was obtained for flasks rotated at $100 \mathrm{rpm}$ (Table 2). Generally higher agitation speeds enhance fluid-to-particle mass transfer which results in higher biomass which could explain that increasing the agitation speed from 0 (microaerophillic condition) to 100 (aerobic condition) resulted in a $4 \%$ increase in log CFU $/ \mathrm{ml}$. However, there was $22.5 \%$ reduction in the growth rate of the cells as the agitation speed was increased from $0 \mathrm{rpm}$ to $100 \mathrm{rpm}$ (Table 3). The difference in growth rates can be attributed to differences in metabolic pathways under aerobic and anaerobic conditions (Murphy and Condon, 1984). Generally, increase in cell numbers in the presence of oxygen is due to generation of additional ATP. Consequently, higher $\log$ CFU $/ \mathrm{ml}$ was seen at $50 \mathrm{rpm}$ and $100 \mathrm{rpm}$. On the other hand, oxygen inhibition associated with superoxide is probably responsible for lower cell growth rate under aerobic conditions (Fu and Mathews, 1999). This might be the reason for relatively lower growth rate but higher biomass for flasks agitated at 50 and $100 \mathrm{rpm}$. It has also been reported that in the presence of oxygen, the metabolism of obligate homofermentative and facultative homofermentative strains switches from the production of lactic acid to acetic acid, thereby increasing the amount of ATP formed (Stolz et al., 1995). This could also explain the higher cell numbers seen when the flasks were rotated at 50 and $100 \mathrm{rpm}$. Tango and Ghaly (1999) also reported that micro-aeration improved the maximum cell numbers. However they also observed an improvement in the specific growth rate which was opposite to the results of the present study. Although, the cell number at the end of $24 \mathrm{~h}$ appeared to be quite similar for all the three rotations, maximum growth rate was achieved at $0 \mathrm{rpm}$. The use of Gompertz equation helped in providing a clear and comprehensive difference in the specific growth rate of $L$. plantarum due to the different rotations.

Similar pattern of growth was seen for L. digitata (Table 2). There was a complete absence of lag phase in the case of L. digitata. The numerical values of the parameter ' $\lambda$ ' are not 


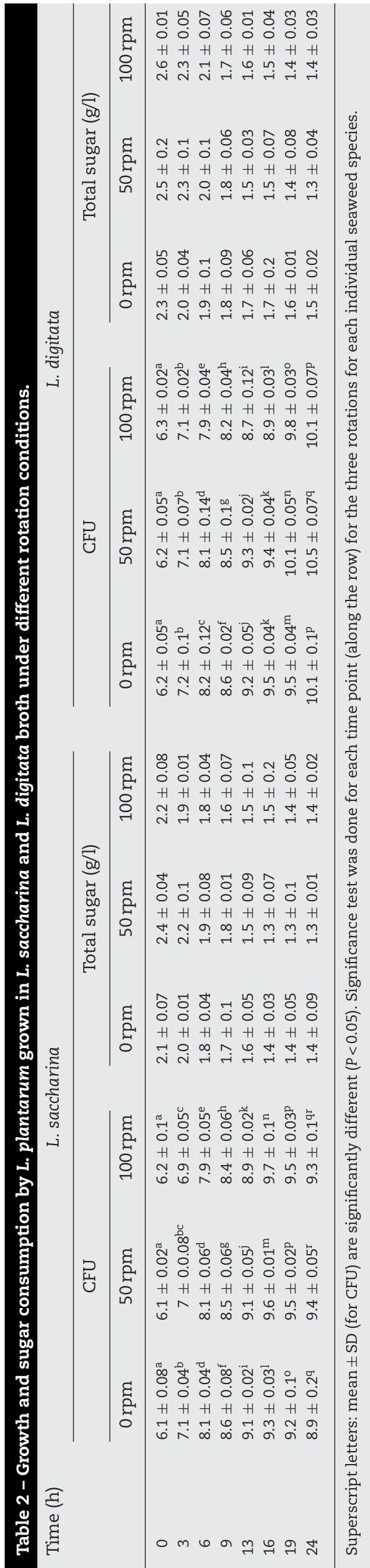

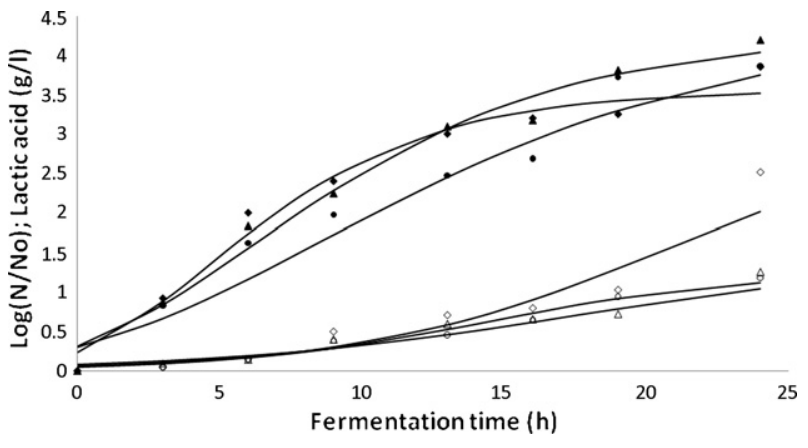

Fig. 2 - Cell growth and lactic acid production with $L$. digitata under different rotation conditions. Legends for $\log \left(\mathrm{N} / \mathrm{N}_{0}\right) \downarrow-0 \mathrm{rpm} ; \Delta-50 \mathrm{rpm}$; $\bullet-100 \mathrm{rpm}$; Legend for lactic acid $\diamond-0 \mathrm{rpm} ; \Delta-50 \mathrm{rpm} ; \bigcirc-100 \mathrm{rpm}$. Smooth lines - model simulated; Points - experimental data.

shown in Table 3 because they were negative (not realistic) and therefore not useful for comparative purposes. The confidence interval for the value of ' $\lambda$ ' includes zero; which indicates that the production of biomass commence from the beginning of the fermentation and the same was evident from the obtained results. The maximal value for cell growth was seen at $24 \mathrm{~h}$ (Fig. 2) for flasks rotated at $50 \mathrm{rpm}$. The cell numbers increased from 6.2 to $10 \log \mathrm{CFU} / \mathrm{ml}$ during the entire fermentation period with a consumption of $0.8-1.2 \mathrm{~g} / \mathrm{l}$ total sugar. The fermentation profile for increase in cell numbers and production of acids for L. digitata can be seen in Fig. 2. There was a $35 \%$ reduction in the growth rate as the rotation speed increased from 0 to $100 \mathrm{rpm}$ (Table 3). A significant difference was observed in log CFU/ml for the flasks rotated at 0,50 and $100 \mathrm{rpm}(P<0.05)$ during the exponential phase (Table 2) which concur with the results obtained by Fu and Mathews (1999). Based on these results, it can be concluded that seaweed broth appeared to be promising as a growth medium for L. plantarum. The culture had the ability to utilize the sugars released from seaweeds and also to grow well in the seaweed substrates. Fruits and vegetable juices can serve as a good medium for the growth of LAB. Nazzaro et al. (2008) evaluated the possibility of producing a functional vegetal beverage based on the growth of Lactobacillus rhamnosus and Lactobacillus bulgaricus in carrot juice. Both bacterial strains were capable of growing in carrot juice, reaching nearly $5 \times 10^{9}$ colony-forming units after $48 \mathrm{~h}$ of fermentation, and the $\mathrm{pH}$ was reduced to 3.5-3.7 or below. Yoon et al. (2005) carried out lactic acid fermentation of beet juice by four species of LAB. All the lactic cultures were found capable of rapidly utilizing beet juice and the viable cell counts for the four bacteria reached $10^{9} \mathrm{CFU} / \mathrm{ml}$ after $48 \mathrm{~h}$ of fermentation. The present study shows that L. plantarum was able to reach $10^{9} \mathrm{CFU} / \mathrm{ml}$ in $16 \mathrm{~h}$ when grown in L. saccharina. The growth of L. plantarum in the seaweeds was comparable with the results obtained from previous workers for cabbage, beet juices and onions (Roberts and Kidd, 2005).

The high level of residual sugars ( $1.4 \mathrm{~g} / \mathrm{l}$ for $\mathrm{L}$. saccharina and 1.3-1.5 g/l for L. digitata) at the end of these fermentations suggests that the growth stopped because of low $\mathrm{pH}$ rather than because of lack of carbohydrate substrate. The level of organic acids at the end of the fermentation might be responsible for the reduction in cell numbers. Studies carried out under controlled $\mathrm{pH}$ conditions have indicated that the accumulation of acids during the fermentation is responsible for decrease in growth rate (Desjardins et al., 1990). 
Table 3 - Parameters for the non-linear regression of Gompertz equation for fitting growth of L. plantarum in seaweeds under different rotation conditions.

\begin{tabular}{|c|c|c|c|c|c|}
\hline & $\mu\left(\mathrm{h}^{-1}\right)$ & $\lambda(\mathrm{h})$ & A & $R^{2}$ & MSE \\
\hline \multicolumn{6}{|c|}{ L. saccharina } \\
\hline $0 \mathrm{rpm}$ & $0.4 \pm 0.02^{\mathrm{a}}$ & 0.46 & $3.16 \pm 0.05^{a}$ & 0.994 & 0.012 \\
\hline $50 \mathrm{rpm}$ & $0.32 \pm 0.03^{b}$ & 0.49 & $3.35 \pm 0.02^{b}$ & 0.986 & 0.029 \\
\hline $100 \mathrm{rpm}$ & $0.31 \pm 0.04^{b}$ & 0.72 & $3.37 \pm 0.07^{b}$ & 0.978 & 0.052 \\
\hline \multicolumn{6}{|l|}{ L. digitata } \\
\hline $0 \mathrm{rpm}$ & $0.29 \pm 0.01^{a}$ & - & $3.6 \pm 0.18^{a}$ & 0.976 & 0.056 \\
\hline $50 \mathrm{rpm}$ & $0.25 \pm 0.01^{b}$ & - & $4.3 \pm 0.13^{b}$ & 0.979 & 0.059 \\
\hline $100 \mathrm{rpm}$ & $0.19 \pm 0.006^{c}$ & - & $4.4 \pm 0.02^{b}$ & 0.962 & 0.127 \\
\hline
\end{tabular}

Superscript letters: mean \pm SD in a column are significantly different $(P<0.05)$. Significance test were done between the three rotations for each species.

Production of lactic acid during fermentation is important as it results in a pH decrease $(<4.0)$ with a concurrent increase in acidity, thus ensuring the microbiological stability of a product during storage. Lactic acid production also seemed to be associated with the agitation speed and followed a pattern similar to that of $\log \mathrm{CFU} / \mathrm{ml}$. In the case of L. saccharina, production of $2.3 \mathrm{~g} / 1$ lactic acid was achieved in $16 \mathrm{~h}$ when fermentation took place at $0 \mathrm{rpm}$ (Fig. 1). Increase in the rotation speed from 0 to $100 \mathrm{rpm}$, resulted in almost $52 \%$ reduction in the production of lactic acid after $16 \mathrm{~h}$ of incubation. A statistically significant difference $(P<0.05)$, in the amounts of lactic acid produced, was observed in the flasks kept at different rotations, ranging from 1 to $1.1 \mathrm{~g} / \mathrm{l}$ after $16 \mathrm{~h}$ of fermentation when compared with the flasks at $0 \mathrm{rpm}(2.3 \mathrm{~g} / \mathrm{l})$, indicating a better acidification performance in the absence of rotation. Since all the fermentations were performed under no $\mathrm{pH}$ control, the organic acids formed via the metabolic pathways reduced the $\mathrm{pH}$ of the broth from 6.6 to 3.9 and the acid production was more intensive during the first $9 \mathrm{~h}$. Analyzing the correlation between the sugar utilization and the lactic acid production by the $L$. plantarum, a high correlation was obtained for the fermentation carried out at $0 \mathrm{rpm}\left(0 \mathrm{rpm}: R^{2}=0.9407\right)$ confirming that homolactic fermentation was dominant; whereas for $50 \mathrm{rpm}$ $\left(R^{2}=0.8875\right)$ and $100 \mathrm{rpm}\left(R^{2}=0.8835\right)$ an average correlation was obtained indicative of a mixed fermentation. Buruleanu et al. (2010) also reported homolactic fermentation for red pepper juice and mixed fermentation for carrot juice based on the correlation between sugar utilization and lactic acid production.

Similarly for L. digitata, the production of lactic acid during fermentation caused a decrease in broth $\mathrm{pH}$, which dropped from 5.0 to 3.5 throughout the exponential growth phase. The amount of lactic acid produced at 50 and $100 \mathrm{rpm}$ was 1.25 and $1.18 \mathrm{~g} / 1$ which was significantly less $(P<0.05)$ than that produced at $0 \mathrm{rpm}(2.5 \mathrm{~g} / \mathrm{l})$. Static (microaerophillic) conditions ( $0 \mathrm{rpm})$ were found to be the better for lactic acid production for both the seaweed species. Analyzing the correlation between the sugar utilization and the lactic acid production by the L. plantarum in terms of $R^{2}$ coefficient, a high correlation was obtained for the fermentation carried out at $0 \mathrm{rpm}$ (0 rpm: $\left.R^{2}=0.977\right)$ and for $50 \mathrm{rpm}\left(R^{2}=0.8281\right)$ and $100 \mathrm{rpm}\left(R^{2}=0.8539\right)$ an average correlation was obtained. Lactic acid fermentation has also been carried out for onions by using either brine from sauerkraut or slices of cabbage as inoculum (Roberts and Kidd, 2005). The fermentation produced sour onion with $\mathrm{pH}$ between $3.25-3.35$ and $1.2-1.5 \mathrm{~g}$ lactic acid/100 $\mathrm{ml}$ in 14 days. The amount of lactic acid produced in the present study for both the seaweed species was less as compared to the above study for onions but the fermentation was completed in much shorter time. The production of acetic acid was minimal increasing only after $19 \mathrm{~h}$. Maximum production of $0.06 \mathrm{~g} / \mathrm{l}$ and $0.05 \mathrm{~g} / \mathrm{l}$ acetic acid was seen at $24 \mathrm{~h}$ for flasks rotated at 50 and $100 \mathrm{rpm}$ for L. saccharina. Almost similar results were seen for $\mathrm{L}$. digitata wherein maximal acetic acid production of 0.06 and $0.04 \mathrm{~g} / 1$ occurred at $24 \mathrm{~h}$ at 50 and $100 \mathrm{rpm}$, respectively. Although L. plantarum is a homo-fermentative bacterium, studies are available which report that cultures of L. plantarum can alter their metabolism in response to different environmental changes. Aerated cultures produce acetate at the expense of lactate during prolonged incubation or at low hexose concentrations (Bobillo and Marshall, 1991; Murphy and Condon, 1984). In the present study also, nil or less than $0.01 \mathrm{~g} / \mathrm{l}$ of acetic acid was seen in flasks incubated at 0 rpm whereas in case of aerated flasks increase in the concentration was seen in the later part of the fermentation. Panagou et al. (2008) also detected production of acetic acid after prolonged fermentation of black olives with $L$. pentosus. They attributed the presence of this organic acid to a shift from homo- to hetero-fermentative metabolism of the starter cultures under conditions of environmental stress such as oxygen and nutrient limitation, salt concentration and low $\mathrm{pH}$ levels.

However, the ratio of lactic/acetic acid obtained in the present study was very high. During the fermentation of seaweeds, the production of lactic acid was more intensive than acetic acid. Upon completion of fermentation 1-1.25 g/l of lactic acid was produced and only $0.04-0.06 \mathrm{~g} / \mathrm{l}$ acetic acid was produced at 50 and $100 \mathrm{rpm}$. Numerous studies dealing with nutrients necessary for lactic acid fermentation have ascertained the fact that high nitrogen content in the growth media will result in higher concentrations of lactic acid (Nancib et al., 2001, 2005). A recent study also showed that high mineral content in carrot juice improved the lactic acid fermentation (Bergqvist et al., 2005). Overall, this led to the conclusion that seaweed broth being a good source of nitrogen and minerals resulted in production of more lactic acid than acetic acid.

The presence of citric acid was seen in traces at the onset of fermentation. However, it was not detectable in the later part of the fermentation and hence was assumed to be metabolized. The presence of malic acid was not detected in the fermented broth. Panagou et al. (2008) also reported the presence of citric acid in traces at the beginning of fermentation of black olives which were degraded completely during the process. 
Table 4 - Value of parameters by non-linear regression of lactic acid produced by seaweeds under different rotation conditions. Values in brackets are the confidence intervals.

\begin{tabular}{|c|c|c|c|c|c|}
\hline & $P_{0}(g / l)$ & $P_{m}(g / l)$ & $P_{r}\left(h^{-1}\right)$ & $R^{2}$ & MSE \\
\hline \multicolumn{6}{|c|}{ L. saccharina } \\
\hline $0 \mathrm{rpm}$ & $0.025(-0.03$ to 0.08$)$ & $2.25(1.9-2.5)$ & $0.42(0.18-0.66)$ & 0.983 & 0.023 \\
\hline $50 \mathrm{rpm}$ & $0.01(-0.03$ to 0.04$)$ & $0.96(0.8-1.1)$ & 0.62 (-0.01 to 1.3$)$ & 0.957 & 0.013 \\
\hline $100 \mathrm{rpm}$ & $0.01(-0.02$ to 0.05$)$ & $0.91(0.8-1)$ & $0.55(0.2-0.8)$ & 0.981 & 0.006 \\
\hline \multicolumn{6}{|l|}{ L. digitata } \\
\hline 0 rpm & $0.06(-0.03$ to 0.16$)$ & $3.1(1-5)$ & $0.19(0.08-0.3)$ & 0.98 & 0.078 \\
\hline $50 \mathrm{rpm}$ & $0.08(-0.03$ to 0.2$)$ & $1.42(0.4-2.4)$ & $0.16(0.03-0.3)$ & 0.95 & 0.018 \\
\hline $100 \mathrm{rpm}$ & $0.05(-0.01$ to 0.1$)$ & $1.26(0.9-1.6)$ & $0.22(0.1-0.3)$ & 0.98 & 0.006 \\
\hline
\end{tabular}

Table 4 lists the values determined for regression parameters $P_{m}, P_{r}$ and $P_{0}$ obtained through Eq. (3). A comparison of predicted and experimental values for lactic acid can be seen in Figs. 1 and 2. The kinetic pattern obtained was reasonably described by the model equation with $R^{2}>0.957$ for the seaweed species at the three different rotations. The maximum lactic acid concentration $\left(P_{m}\right)$ was achieved for flasks incubated at $0 \mathrm{rpm}$ for both the seaweed species. No general trend was observed for the rate of lactic acid production $\left(P_{r}\right)$. Although the rate seemed to be higher for the flasks kept at $50 \mathrm{rpm}$ but the presence of aerobic conditions might have suppressed the lactic acid production. Even though L. digitata had a higher value of $P_{m}(3.1 \mathrm{~g} / \mathrm{l})$ as compared to $L$. saccharina $\left(P_{m}=2.25 \mathrm{~g} / \mathrm{l}\right)$ for $0 \mathrm{rpm}$, the rate of production of lactic acid $\left(P_{r}\right)$ was better for L. saccharina. The fermentation of L. digitata followed a slower kinetics and more time was needed to achieve similar amount of cell growth and lactic acid production. The numerical values of the parameter ' $\mathrm{P}_{0}$ ' were also found to be non-realistic because the confidence interval included zero, which indicated that the amount of lactic acid at the beginning of the fermentation should be close to zero which is practically true and was also evident from the obtained results. The model was validated by comparing predicted and observed values and the mean square error was found to be less than 0.08 (Table 4).

\section{Conclusions}

Three species of edible Irish brown seaweeds were used as a sole source of nutrition for fermentation upon using lactic acid bacteria. Raw and heat treated forms of the studied species were tested for fermentation. Out of the three, heat treated L. digitata and L. saccharina have proven to be suitable substrates for lactic acid fermentation by L. plantarum. The highest cell populations were obtained for L. digitata; however, L. saccharina resulted in a faster fermentation as maximum cell growth was achieved in a lesser time. Thereby, they provide an attractive opportunity to utilize such a vast seaweed resource in the development of new functional foods. The model equations used herein allowed description of the microbial kinetics and characterization of the main culture production. The parameters thus obtained were very useful for a comparison of cultures kinetics under different conditions. The good adaptation of lactic acid bacteria in the heat processed seaweeds advocate the fact that if a potentially probiotic strain is used as a starter culture then it might produce a fermented seaweed product with defined and consistent characteristics and possibly health-promoting properties. However, several technological aspects have to be considered in the design of such a novel food fermentation process such as the growth capability and productivity of the starter culture and the stability of the final product during storage.

\section{Acknowledgements}

The authors would like to acknowledge funding from the Irish government under the Technological Sector Research Scheme (Strand III) of the National Development Plan.

\section{Appendix A.}

$\mu_{\max } \quad$ maximum specific growth rate of cell population $\left(\mathrm{h}^{-1}\right)$

A $\quad \log$ increase in population

$\mathrm{N} \quad \mathrm{CFU} / \mathrm{ml}$ at any time $t$

$\mathrm{N}_{0} \quad$ initial CFU/ml

$P \quad$ lactic acid concentration $(\mathrm{g} / \mathrm{l})$

$P_{m} \quad$ maximum concentration of lactic acid (g/l)

$P_{0} \quad$ initial product concentration $(g / l)$

$P_{r} \quad$ ratio between the initial volumetric rate of product formation $\left(r_{p}\right)$ and the initial product concentration $\mathrm{P}_{0}\left(\mathrm{~h}^{-1}\right)$

time $(\mathrm{h})$

delayed time variable (lag phase) $(\mathrm{h})$

\section{References}

Bello, J., Sánchez Fuertes, M.A., 1995. Application of a mathematical model to describe the behaviour of the Lactobacillus spp. during the ripening of a Spanish sausage (chorizo). Int. J. Food Microbiol. 27, 215-227.

Bergqvist, S.W., Sandberg, A.-S., Carlsson, N.-G., Andlid, T., 2005. Improved iron solubility in carrot juice fermented by homoand hetero-fermentative lactic acid bacteria. Food Microbiol. 22, 53-61.

Bobillo, M., Marshall, V.M., 1991. Effect of salt and culture aeration on lactate and acetate production by Lactobacillus plantarum. Food Microbiol. 8, 153-160.

Burgos-Rubio, C.N., Okos, M.R., Wankat, P.C., 2000. Kinetic studies of the conversion of different substrates to lactic acid using lactobacillus bulgaricus. Biotechnol. Prog. 16, 305-314.

Buruleanu, L., Nicolescu, C.L., Bratu, M.G., Manea, I., Avram, D. 2010. Study regarding some metabolic features during lactic acid fermentation of vegetable juices. Rom. Biotechnol. Lett. 15, 5177-5188.

Cagno, R.D., Surico, R.F., Siragusa, S., De Angelis, M., Paradiso, A., Minervini, F., De Gara, L., Gobbetti, M., 2008. Selection and use of autochthonous mixed starter for lactic acid fermentation of carrots, French beans or marrows. Int. J. Food Microbiol. 127, 220-228. 
Cagno, R.D., Surico, R.F., Paradiso, A., De Angelis, M., Salmon, J.C., Buchin, S., De Gara, L., Gobbetti, M., 2009. Effect of autochthonous lactic acid bacteria starters on health-promoting and sensory properties of tomato juices. Int. J. Food Microbiol. 128, 473-483.

Daeschel, M.A., Fleming, H.P., McFeeters, R.F., 1988. Mixed culture fermentation of cucumber juice with Lactobacillus plantarum and yeasts. J. Food Sci. 53, 862-864.

de Vries, M.C., Vaughan, E.E., Kleerebezem, M., de Vos, W.M., 2006. Lactobacillus plantarum - survival, functional and potential probiotic properties in the human intestinal tract. Int. Dairy J. 16, 1018-1028.

Desjardins, M.-L, Roy, D., Toupin, C., 1990. Uncoupling of growth and acids production in Bifidibacterium spp. J. Dairy Sci. 73, 1478-1484.

Dubois, M., Gilles, K.A., Hamilton, J.K., Rebers, P.A., Smith, F., 1956. Colorimetric method for determination of sugars and related substances. Anal. Chem. 28, 350-356.

Echevarria, R., Bautista-Gallego, J., Arroyo-López, F.N., Garrido-Fernández, A., 2010. Modelling the effect of ascorbic acid, sodium metabisulphite and sodium chloride on the kinetic responses of lactic acid bacteria and yeasts in table olive storage using a specifically implemented Quasi-chemical primary model. Int. J. Food Microbiol. 138, 212222.

Ennouali, M, Ouhssine, M., Ouhssine, K., Elyachioui, M., 2006. Biotransformation of algal waste by biological fermentation Afr. J. Biotechnol. 5, 1233-1237.

Fleurence, J., 1999. Seaweed proteins: biochemical, nutritional aspects and potential uses. Trends Food Sci. Technol. 10, 25-28.

Fu, W, Mathews, A.P., 1999. Lactic acid production from lactose by Lactobacillus plantarum: kinetic model and effects of $\mathrm{pH}$, substrate, and oxygen. Biochem. Eng. J. 3, 163-170.

Fujii, T., 1992. Fermentation of water soluble polysaccharides of brown algae by human intestinal bacteria in vitro. Nippon Suisan Gakk 58, 147-152.

Gardner, N.J., Savard, T., Obermeier, P., Caldwell, G., Champagne, C.P., 2001. Selection and characterization of mixed starter cultures for lactic acid fermentation of carrot cabbage, beet and onion vegetable mixtures. Int. J. Food Microbiol. 64, 261-275.

Ge, X.Y., Qian, H., Zhang, W.-G., 2009. Improvement of l-lactic acid production from Jerusalem artichoke tubers by mixed culture of Aspergillus niger and Lactobacillus sp. Bioresour. Technol. 100, 1872-1874.

Gupta, S., Rajauria, G., Abu-Ghannam, N., 2010. Study of the microbial diversity and antimicrobial properties of Irish edible brown Seaweeds. Int. J. Food Sci. Technol. 45, 482-489.

Kandler, O., 1983. Carbohydrate metabolism in lactic acid bacteria. Antonie van Leeuwenhoek 49, 209-224.

Karovićová, J., Kohajdová, Z., 2003. Lactic acid-fermented vegetable juices - palatable and wholesome foods. Chem. Pap. $59,143-148$

Kedia, G., Vázquez, J.A., Pandiella, S.S., 2008. Fermentability of whole oat flour, PeriTec flour and bran by Lactobacillus plantarum. J. Food Eng. 89, 246-249.

Kohajdová, Z., Karovićová, J., Greifova, M., 2006. Lactic acid fermentation of some vegetables juices. J. Food Nutr. Res. 45 115-119.

Kuda, T., Fujii, T., Saheki, K., Hasegawa, A., Okuzumi, M., 1992a Effects of brown algae on faecal flora of rats. Nippon Suisan Gakk 58, 307-314

Kuda, T., Fujii, T., Saheki, K., Hasegawa, A., Okuzumi, M., 1992b. Effect of degraded products of laminaran by Clostridium ramosum on the growth of intestinal bacteria. Nippon Suisan Gakk 58, 1307-1311.

Kuda, T., Goto, H., Yokoyama, M., Fujii, T., 1998. Fermentable dietary fiber in dried products of brown algae and their effects on cecal microflora and levels of plasma lipid in rats. Fish Sci. $64,582-588$

Kun, S., Rezessy-Szabó, J.M., Nguyen, Q.D., Hoschke, A., 2008. Changes of microbial population and some components in carrot juice during fermentation with selected Bifidobacterium strains. Proc. Biochem. 43, 816-821.

Kyung, K.H., Fleming, H.P., 1994. Antibacterial activity of cabbage juice against lactic acid bacteria. J. Food Sci. 59, 125129.

Luckow, T., Delahunty, C., 2004. Which juice is 'healthier'? A consumer study of probiotic non-dairy juice drinks. Food Qual. Pref. 15, 751-759.

Mabeau, S.J., Fleurence, J., 1993. Seaweed in food products: biochemical and nutritional aspects. Trends Food Sci. Technol. 4, 103-107.

Mecozzi, M., 2005. Estimation of total carbohydrate amount in environmental samples by the phenol-sulphuric acid method assisted by multivariate calibration. Chemomtr. Intell. Lab. Syst. 79, 84-90.

Mercier, P., Yerushalmi, L., Rouleau, D., Dochain, D., 1992. Kinetics of lactic acid fermentation on glucose and corn by Lactobacillus amylophilus. J. Chem. Technol. Biotechnol. 55, 111-121.

Michel, C., Lahaye, M., Bonnet, C., Mabeu, S., Barry, J.L., 1996. In vitro fermentation by human faecal bacteria of total and purified dietary fibres from brown seaweeds. Br. J. Nutr. 75 (26), 1-80.

Murphy, M.G., Condon, S., 1984. Comparison of aerobic and anaerobic growth of Lactobacillus plantarum in a glucose medium. Arch. Microbiol. 138, 49-53.

Murphy, M.G., O'Connor, L., Walsh, D., Condon, S., 1985. Oxygen dependent lactate utilization by Lactobacillus plantarum. Arch. Microbiol. 141, 75-79.

Nazzaro, F., Fratianni, F., Sada, A., Orlando, P., 2008. Synbiotic potential of carrot juice supplemented with Lactobacillus spp. and inulin or fructooligosaccharides. J. Sci. Food Agric. 88, 2271-2276.

Nancib, A., Nancib, N., Meziane-Cherif, D., Boubendir, A., Fick, M., Boudrant, J., 2005. Joint effect of nitrogen sources and B vitamin supplementation of date juice on lactic acid production by Lactobacillus casei subsp. rhamnosus. Bioresour. Technol. 96, 63-67.

Nancib, N., Nancib, A., Boudjelal, A., Benslimane, C., Blanchard, F., Boudrant, J., 2001. The effect of supplementation by different nitrogen sources on the production of lactic acid from date juice by Lactobacillus casei subsp. rhamnosus. Bioresour. Technol. 78, 149-153.

Panagou, E.Z., Schillinger, U., Franz, C.M.A.P., Nychas, G.J.E., 2008 Microbiological and biochemical profile of cv Conservolea naturally black olives during controlled fermentation with selected strains of lactic acid bacteria. Food Microbiol. 25, 348-358.

Prachyakij, P., Charernjiratrakul, W., Kantachote, D., 2008. Improvement in the quality of a fermented seaweed beverage using an antiyeast starter of Lactobacillus plantarum DW3 and partial sterilization. World J. Microbiol. Biotechnol. 24, 1713-1720.

Roberts, J.S., Kidd, D.R., 2005. Lactic acid fermentation of onions. Lebensmittel-Wissenschaft und-Technologie 38, 185190.

Schofield, P., Pitt, R.E., Pell, A.N., 1994. Kinetics of fiber digestion from in vitro gas production. J. Anim. Sci. 72, 2980-2991.

Smit, A.J., 2004. Medicinal and pharmaceutical uses of seaweed natural products: a review. J. Appl. Phycol. 16, 245-262.

Stolz, P., Böcker, G., Hammes, W.P., Vogel, R.F., 1995. Utilization of electron acceptors by lactobacilli isolated from sourdough: I. Lactobacillus sanfransisco. Z. Lebensm. Unters. Forsch. 201, 91-96.

Suzuki, T., Ohsugi, Y., Yoshie, Y., Shirai, T., Hirano, T., 1996. Dietary fiber content, water-holding capacity and binding capacity of seaweeds. Fish Sci. 62, 454-461.

Tango, M.S.A, Ghaly, A.E., 1999. Amelioration of lactic acid production from cheese whey using micro-aeration. Biomass Bioeng. 17, 221-238.

Uchida, M., Murata, M., 2002. Fermentative preparation of single cell detritus from seaweed, Undaria pinnatifida, suitable as a replacement hatchery diet for unicellular algae. Aquaculture 207, 345-357. 
Yoon, K.Y, Woodams, E.E., Hang, Y.D., 2005. Fermentation of beet juice by beneficial lactic acid bacteria. LebensmittelWissenschaft und-Technologie 38, 73-75.

Yoon, K.Y., Woodams, E.E., Hang, Y.D., 2006. Production of probiotic cabbage juice by lactic acid bacteria. Bioresour. Technol. 97, 1427-1430.
Zwietering, M.H., Jongenburger, I., Rombouts, F.M., Van't Riet, K., 1990. Modelling of the bacterial growth curve. Appl. Environ. Microbiol. 56, 1875-1881. 